\title{
50
}

\section{Shared Space and the Regulation of Legal Education}

\author{
Paul Maharg
}

\section{Introduction}

Rebecca is a new member of staff in the new University of Kioloa Law School. She is an environmental lawyer, loves teaching and learning and thinks the subject of her research so important that, in the words of Naomi Klein, this changes everything. She wants to design an entirely new law curriculum for students and structure it thematically in environmental law. Every subject will be taught in part through the lens of the environment - environmental regulation and the part it can play in many subjects within the legal curriculum; the history of environmental concern, and the history of indigenous cultures' sustainable use of land and sea; the history and science of climate change, the place of policy and role of governmental intervention, the rise of consumer movements resisting commercial exploitation of the world's resources, and much else. It will have options in law, literature and the environment, re-wilding nature, the future of sustainable cities, and the like. And it will be entirely online. It's designed not just for students interested in environmental law, but for anyone doing any job linked to the environment in, for example, regulation, policy, innovation, bioscience, medscience, enforcement and

1 Professor, The Australian National University College of Law. 
much else. Professional accreditation in law might be integrated, possibly in other disciplines too, as optional streams. It will include a Masters option as well which, being offered online, will be available internationally.

Her Dean can see the idea working financially and supports it politically at the Law School Management Group, and staff are interested, all the more so in that the small group of environmental lawyers in the Law School, all equally interested in the idea, will be doing most of the design work on the curriculum and will be fronting-up the proposal for accreditation.

But what's required of accreditation? She begins to map it out. First there's the Law School Teaching and Learning Committee that has to approve the general curriculum design and the individual subjects; and since this is a new curriculum, it will want to see marketing reports and staff resource reports (to ensure the Law School can resource the proposal) and much else. Then the proposal goes to the University Education Committee which is far from a rubber-stamp job, and will look at how the curriculum affects the university brand, amongst other issues. Then NSW accreditation is sought. There is liaison with the profession, with environmental groups, and many others.

Next she begins to think about how the curriculum will be judged at the various stages. She looks at the current (2016) regulatory guidelines for higher education (HE) programs in Law in Australia, which include the following:

\section{Council of Australian Law Deans (CALD) Standards;}

2. Australian Qualifications Framework (AQF);

3. TEQSA HE Standards Framework (Threshold Standards) 2015 (with a new framework that came into force 1 January 2017);

4. Learning and Teaching Academic Standards Statement;

5. Generic Framework on Internationalising the Law Curriculum;

6. National PLT Competences. ${ }^{2}$

2 CALD Standards are available at www.cald.asn.au/docs/CALD\%20-\%20standards\%20project\%20 -\%20final\%20-\%20adopted\%2017\%20November\%202009.pdf. Australian Qualifications Framework; see www.aqf.edu.au. The TEQSA provides an overview of the new HE Standards Framework, www.teqsa. gov.au/teqsa-contextual-overview-hes-framework. The Academic Standards Statement is available at www. cald.asn.au/assets/lists/ALSSC\%20Resources/KiftetalLTASStandardsStatement2010.pdf. The CALD

Internationalising Framework is set out at curriculum.cald.asn.au/generic-framework/. 
She is dismayed by the cascade of standards, competences, statements, guidelines, outcomes, many of them overlapping, sometimes contradictory, expressed in vague lexis that gives little real indication of actual educational standards. There is no meta-document that guides her through all this, or the maze of accreditation process across Australia's states and territories. How is her innovation going to survive such weight of regulatory command and admonition? On closer inspection, each code bears the marks of its makers, their interpretation of what legal education has been, their present anxieties, their attempt to prescribe the future and to close down and command. But these are not her anxieties or her hopes. She, not they, will be designing the innovative program and helping students learn. But already she can feel her excitement fading at the sheer scale of this task. She puts the project to one side. Maybe next year.

\section{Regulation and the Anxiety of Influence}

What Rebecca faces is the result of 'decentred regulation' which, as Black describes it, is characterised by five factors: complexity, fragmentation, interdependence, overlapping public and private interests, and ungovernability. ${ }^{3}$ Extensive regulation begets more regulation, in spite of best practice codes arguing for the opposite, which increases tension and competition between the regulatory actors and further destabilises the field. ${ }^{4}$ There is almost no empirical evidence to support the concept that educational quality will be improved by greater competition accompanied by less regulation. On the other hand, it is well known that a greater volume of regulation does not necessarily lead to better education. This was recognised by the then DIICCSRTE (Department of Industry, Innovation, Climate Change, Science, Research and Tertiary Education) which commissioned a report to reduce regulatory burden on Australian HE generally. The aim was laudable, but could only mitigate against an ungovernable system that will inevitably grow in size and complexity. ${ }^{5}$

3 Julia Black, 'Decentring Regulation: Understanding the Role of Regulation and Self-Regulation in a "Post-Regulatory” World' (2001) 54 Current Legal Problems 103.

4 See Judith Healy and Paul Dugdale, 'Regulatory Strategies in Safer Patient Health Care' in Judith Healy and Paul Dugdale (eds), Patient Safety First: Responsive Regulation in Health Care (Allen \& Unwin, 2009) 1.

5 See Kwong Lee Dow and Valerie Braithwaite, Review of Higher Education Regulation (Commonwealth of Australia, 2013) Appendix A, 'Assuring Quality While Reducing the Higher Education Regulatory Burden'. 
This is by no means limited to Australian legal education. In recent decades legal education regulation internationally has accelerated in volume, pace and intensity. ${ }^{6}$ In the last decade we can cite seven such movements. In 2006-9 the Law Society of Scotland laid aside a smallscale review of the primary program in professional training, to review, nationally, the entire legal educational process, from day one of law school through to point of qualification after traineeship (and there was also consideration of Continuing Professional Development, CPD). ${ }^{7}$ In Canada, the Federation of the Law Societies of Canada carried out, like the Law Society of Scotland, two years of national consultation relating to criteria for approving common law degrees for the purpose of entry into bar admission programmes in Canada. ${ }^{8}$

Meanwhile in England the three leading regulators of professional education, CILEx (Legal Executives), the Bar Standards Board (BSB) and the Solicitors Regulation Authority (SRA) began the lengthy process of reviewing professional legal education in what eventually became known as the Legal Education and Training Review (2011-13). The context for the review included the effects of liberalisation of the legal services market, implemented by the Legal Services Act 2007, and the report was published in 2013. ${ }^{9}$

The US has seen considerable upheaval in legal education since the onset of the global financial crisis, which has resulted in significant downturn in the numbers of positions for young lawyers, and subsequently the numbers of students entering law schools. This, together with dissatisfaction regarding many issues of regulation of legal education, led to the formation of the American Bar Association (ABA) Task Force which took a little over a year to report on the situation in US law schools. ${ }^{10}$ Concurrently, the

6 Julian Webb et al, 'Setting Standards. The Future of Legal Services Education and Training Regulation in England and Wales' (SRA, BSB, IPS, 2013), letr.org.uk. The authors summarised this in their Literature Review, and brought up to date earlier analyses of the reform movement. Numerous articles confirm this; for example, Andrew Boone and Julian Webb, 'Legal Education and Training in England and Wales: Back to the Future?' (2008) 58 Journal of Legal Education 79.

7 See www.lawscot.org.uk/education-and-careers/education-and-training-policy/.

8 See flsc.ca/national-initiatives/canadian-law-school-programs/.

9 See letr.org.uk for the report and associated Literature Review.

10 Two reports were produced: one on the future of American law schools (see www.americanbar. org/groups/professional_responsibility/taskforceonthefuturelegaleducation.html) and another on the future of the financing of legal education (see www.americanbar.org/groups/legal_education/ committees/aba-task-force-on-the-financing-of-legal-education-.html). For commentary, see Richard L Abel, "You Never Want a Serious Crisis to Go to Waste": Reflections on the Reform of Legal Education in the US, UK, and Australia' (2015) 22 International Journal of the Legal Profession 3. 
Canadian Bar Associations began the first comprehensive study of the state of the Canadian legal market, called the Legal Futures Initiative, which culminated in a report completed in 2014 called Futures: Transforming the Delivery of Legal Services in Canada. ${ }^{11}$ Significantly, the report and the initiative went hand-in-hand with another called the Equal Justice Initiative, both of them having implications for the future of Canadian legal education.

In Australia meanwhile the Law Admissions Consultative Committee began to review legal educational processes and standards in a Review of Academic Requirements. In their initial report (completed in 2015) they noted the great variety of standards, codes and outcomes populating the regulatory space in Australia, and cited the LETR Report as follows:

the [LETR] report notes the lack of an overall and coherent legal education system as such. That being so, and in order to avoid a tournament of regulators as to who will regulate whom, the regulators are encouraged to consider greater collaboration ...

The report also identifies a number of overarching issues for the regulators, designed to promote common learning outcomes and consistency. ${ }^{12}$

Most recently, the Law Society of Hong Kong has instructed a review of legal education, reporting in late 2016, following an earlier report that was prepared on the subject of a common entry examination, but which has not yet been released by the Law Society.

All this activity denotes what the literary critic Harold Bloom has termed the anxiety of influence. There are complex relations between regulators internationally as they watch each other and the actors around them. Strong regulators struggle with their predecessors and their peers, in much the same way as writers do with other strong writers; and such leading regulators give models of action for regulators in other jurisdictions. As Bloom observes, ' $[\mathrm{t}$ ] deconstruct a poem is to indicate the precise location of its figuration of doubt, its uncertain notice of that limit where

11 See www.cba.org/CBA-Legal-Futures-Initiative/Home/ for information on the Initiative. The report cited above is available at www.cba.org/CBA-Legal-Futures-Initiative/Reports/FuturesTransforming-the-Delivery-of-Legal-Service.

12 The report is entitled Review of Academic Requirements for Admission to the Legal Profession, www.lawcouncil.asn.au/LACC/images/pdfs/01.12.14_-_Review_of_Academic_Requirements_for_ Admission.pdf. 
persuasion yields to a dance or interplay of tropes'. ${ }^{13}$ For Bloom, there were two broad categories of poetic tropes: 'tropes of action and tropes of desire'. ${ }^{14}$ Replace the word 'poem' with that of 'report', and we have a precise description of many legal education regulators, caught between a deepening anxiety of influence and the need to persuade, and the tropes of desire and of action that lead them to attempt to regulate and command.

\section{Disintermediation and Regulation}

But is such regulation best for legal education? Could it be that we have, fundamentally, the wrong mode of regulatory activity? Let us think about the meta-activities that law schools are engaged in, the activities that Rebecca will engage in, should her program ever see the light of day. At the heart of law schools, and this is true of the earliest in 1088 at Bologna as it is of the most recently-formed law school such as the University of Kioloa, lies a highly complex process of mediation. Such mediation includes the activities of curation, of innovation and of learning knowledge, skill and value, all processes highly intertwined with each other. We preserve the past in order to transmit it to the future. But we also have a duty to critique, interpret and innovate, through analysis of myriad legal cultures, their performativities and their fields and habitus. ${ }^{15}$ We also learn, and we help our students to learn, how to curate, interpret, reason, practise skill, and learn value. Above all, legal scholars mediate the past and prepare students for the future; and how we do that is as much a domain of jurisprudential activity as any other sub-domain of that area of law. It is also essentially an interdisciplinary activity.

13 Harold Bloom, The Anxiety of Influence. A Theory of Poetry (Oxford University Press, 1974) 308. 'Tropes' is a key term for Bloom. It refers, generally, less to the rhetorical sense of a figure or device (i.e. a static collection of terms such as metaphor, metonymy, and the like), and more to the psychological moves a writer makes within a precise historical context to persuade a reader.

14 Ibid. 401.

15 Arising from linguistics and the philosophy of language, a performativity is not simply an utterance or performance, but an act that effects or affects identity and action. A judge pronouncing a judgment is a typical example; a promise is another, particularly when treated legally as actionable, as in the construct of pollicitatio under Roman Law. The concept of a field or habitus derives of course from Bourdieu. See, for example, Pierre Bourdieu and Jean Passeron, Reproduction in Education, Society and Culture (Sage, 1977). The idea of the 'habitus' has been highly influential in education, describing as it does the enduring and transferable dispositions in society that affect individuals, as embodied for example in the notion of 'cultural capital'. For a critique of the latter concept based upon empirical educational research carried out at Oxford University, see Anna Zimdars, Alice Sullivan and Anthony Heath, 'Elite Higher Education Admissions in the Arts and Sciences: Is Cultural Capital the Key?’ (2009) Sociology 43, 648. 
Such mediation, however, is subject to intermediation by technologies, by economic and political forces, by social and institutional agents and by innovation. And it is subject to disintermediation - to the disruption in the process by which established intermediaries (other processes, workflows, technologies, agents) are removed or replaced, or the process itself is reconfigured. Disintermediation is an essential element of historical change in law school mediation, present most strikingly in the digital revolution of the past few decades, but present in all legal education. ${ }^{16}$

Regulators and their codes rarely acknowledge the constant process of disintermediation. Their reports and codes are often the result of a set of social pressures upon legal education or higher education, but, caught in tropes of desire and action, they often seek the autopoiesis of closure. ${ }^{17}$ They attempt to close down or remediate the effects of those pressures through the design and enforcement of a code or a set of recommendations. Meanwhile social pressures such as those brought on by disintermediation have already morphed and produced new, often unforeseen and rarely intended educational and social consequences around the new code or recommendations. We need an approach to regulation that eschews the hierarchical command of much regulatory practice in the field and instead seeks to understand the effects of disintermediation and other social processes within law school assemblages and networks.

\section{The Shared Space: A Portrait of the Regulator as Collaborator}

Much of the architecture of regulation in Australian HE is built upon the regulatory principles of risk, necessity and proportionality - principles that have been derived from other systems of regulation but which I would argue are of themselves insufficient to provide ethical and effective regulation for higher education. What may be required is:

16 Paul Maharg, 'Disintermediation' (2016) 50 The Law Teacher 114.

17 As many commentators have pointed out, the self-reproductive power of a system such as a legal system lies in its ability to be at once open and closed: it is autopoietic. Teubner described how, 'unlike neo-liberal and structuralist theories', autopoiesis emphasises 'the complex, the local, the closed and the unstable against global, coherent, artificing and equilibrating mechanisms': Gunther Teubner (ed), Autopoietic Law: A New Approach to Law and Society (Walter de Gruyter, 1988) 9. For regulators, the concept of closure is a dominant one, where the dynamic play of agents and the creative power of collaborative action are seen as a threat to the command model of regulation, which seeks the stasis of control. 
1. A new attitude to Open Education and Open Research, and the encouragement of co-production and of communities of practice across educational institutions and across disciplines and professions.

2. A view of regulation as comprising not just quality assurance but quality enhancement, where responsibility is given to the actors in the regulated field to regulate their own behaviour according to their own aims, subject to monitoring.

In the Legal Education and Training Review Report we advocated, inter alia, an approach to regulation that we called the 'shared space'. It was summarised in the report as the sustained development of 'a community of educators, regulators, policy-makers and professionals working in provision of legal services, drawing information from other jurisdictions, other professions and other regulators to identify best practices in [legal education] and its regulation' (para 6.158). The approach was outlined in more detail in Ch 3 of the LETR Literature Review, where we investigated the role that design played in the shared space, contrasting it with role played by hierarchical regulation, and the potential it had to shape regulated activity:

Design can be used to enhance responsibility and accountability, and extend agency ...; indeed it can do so by clearing a space, as it were, in hierarchy so that self-governance, often according to extra-legal norms, is possible in ways that it would not otherwise be within communities of practice. $^{18}$

We recommended that the frontline regulators of legal education form a Legal Council to provide the neutral space for regulators, providers and many others to meet and plan this new approach. In their report, Lee Dow and Braithwaite similarly recommended the formation of an Advisory Council and a collaborative approach to co-regulation and self-regulation which describes regulators and institutions working in partnership. As Raban and Cairns describe it, citing Lee Dow and Braithwaite:

They would need to 'share the same objective (excellence in teaching, learning and research, for example)' and 'the purpose of the regulatory encounter' should be 'to raise concerns about risks and obstructions to achieving (these) objectives and to work through problems to find a satisfactory solution'. ${ }^{19}$

18 Ibid. Ch 3, para 45.

19 Colin Raban and David Cairns, 'How Did It Come to This?' (2014) 18 Perspectives: Policy and Practice in Higher Education 112, 117. 
But excellence in teaching and learning is, as an aim, so high-level that in practice it means little. And under the top-down model of regulation, which still is the essence of this regulatory relationship, the hidden agendas of what constitutes excellence threaten to silence the shared conversation. Institutions will try to second-guess what constitutes excellence in the eyes of the regulator. The regulator will point to market devices (e.g. student choice) as proxies for excellence, an argument advanced by the Browne Report in the UK, and by Universities Australia, and dismissed by many academics. ${ }^{20}$

In the shared space by contrast, HE institutions would have much more agency and work closely with others, including regulators. The Scottish model of QE or Quality Enhancement is one model for a partial shared space. Regulators learn as much as institutions do from the process arms-length measurement of quality is not the point of the exercise, where institutions lead the review of themselves, and where both regulation and its processes are streamlined and much more focused. Students there play a key role in the enhancement process. Land and Gordon describe aspects of it thus:

There has been a strong concern to create a sense of ownership and legitimation among all those with a vested interest. In particular, considerable emphasis has been placed on paying attention to the voice(s) of students and encouraging their participation not just as consumers of a service but, after appropriate training, as genuine partners in the review of quality. It has been characterised generally by a shift from audit to improvement, to a more developmental approach, with a focus on teaching and learning themes, and strong emphasis on evaluation and subsequent responsiveness to feedback. ${ }^{21}$

In shared spaces such as this there is the possibility that innovation can be encouraged, disintermediation better understood, and that open cultures can be developed. Along with harmonisation and streamlining of codes in Australian legal education regulation, there is the potential that it could significantly improve legal education regulation. There is even the possibility that, under such a regulatory regime, Rebecca's program might become reality.

20 E J P Browne, 'Securing a Sustainable Future for Higher Education: An Independent Review of Higher Education Funding and Student Finance' (2010), www.independent.gov.uk/browne-report; 'Universities Australia Submission to the Review of Higher Education Regulation' (Universities Australia, 2013).

21 George Gordon and Ray Land, “To See Ourselves as Others See Us”: The Scottish Approach to Quality Enhancement' in George Gordon and Ray Land (eds), Enhancing Quality in Higher Education: International Perspectives (Routledge, 2016) 82. 
This text is taken from New Directions for Law in Australia: Essays in Contemporary Law Reform, edited by Ron Levy, Molly O’Brien, Simon Rice, Pauline Ridge and Margaret Thornton, published 2017 by ANU Press, The Australian National University, Canberra, Australia. 